\title{
Mixing characteristics of refractory black carbon aerosols at an urban site in Beijing
}

\author{
Hang Liu ${ }^{1,2}$, Xiaole Pan ${ }^{1}$, Dantong Liu ${ }^{3}$, Xiaoyong Liu ${ }^{1,4}$, Xueshun Chen ${ }^{1}$, Yu Tian ${ }^{1}$, Yele Sun ${ }^{1,2,4}$, Pingqing Fu ${ }^{5}$, and \\ Zifa Wang ${ }^{1,2,4}$ \\ ${ }^{1}$ State Key Laboratory of Atmospheric Boundary Layer Physics and Atmospheric Chemistry, \\ Institute of Atmospheric Physics, Chinese Academy of Sciences, Beijing, 100029, China \\ ${ }^{2}$ College of Earth Sciences, University of Chinese Academy of Sciences, Beijing, 100049, China \\ ${ }^{3}$ Department of Atmospheric Sciences, School of Earth Sciences, Zhejiang University, \\ Hangzhou, Zhejiang, 310027, China \\ ${ }^{4}$ Center for Excellence in Regional Atmospheric Environment, Chinese Academy of Science, Xiamen, 361021, China \\ ${ }^{5}$ Institute of Surface-Earth System Science, Tianjin University, Tianjin, 300072, China
}

Correspondence: Xiaole Pan (panxiaole@mail.iap.ac.cn)

Received: 16 March 2019 - Discussion started: 20 May 2019

Revised: 6 April 2020 - Accepted: 9 April 2020 - Published: 14 May 2020

\begin{abstract}
Black carbon aerosols play an important role in climate change because they directly absorb solar radiation. In this study, the mixing state of refractory black carbon (rBC) at an urban site in Beijing in the early summer of 2018 was studied with a single-particle soot photometer (SP2) as well as a tandem observation system with a centrifugal particle mass analyzer (CPMA) and a differential mobility analyzer (DMA). The results demonstrated that the mass-equivalent size distribution of $\mathrm{rBC}$ exhibited an approximately lognormal distribution with a mass median diameter (MMD) of $171 \mathrm{~nm}$. When the site experienced prevailing southerly winds, the MMD of rBC increased notably, by $19 \%$. During the observational period, the ratio of the diameter of rBC-containing particles $\left(D_{\mathrm{p}}\right)$ to the $\mathrm{rBC}$ core $\left(D_{\mathrm{c}}\right)$ was 1.20 on average for $D_{\mathrm{c}}=180 \mathrm{~nm}$, indicating that the majority of rBC particles were thinly coated. The $D_{\mathrm{p}} / D_{\mathrm{c}}$ value exhibited a clear diurnal pattern, with a maximum at 14:00 LST and a $D_{\mathrm{p}}$ growth rate of $2.3 \mathrm{~nm} \mathrm{~h}^{-1}$; higher $\mathrm{O}_{x}$ conditions increased the coating growth rate.

The microphysical properties of $\mathrm{rBC}$ were also studied. Bare rBC particles were mostly found in fractal structures with a mass fractal dimensions $\left(D_{\mathrm{fm}}\right)$ of 2.35 , with limited variation during both clean and polluted periods. The morphology of rBC changed with coating thickness increasing. When the mass ratio of nonrefractory matter to $\operatorname{rBC}\left(M_{\mathrm{R}}\right)$ was $<1.5$, rBC-containing particles were primarily found in
\end{abstract}

external fractal structures, and they changed to a core-shell structure when $M_{\mathrm{R}}>6$, at which point the measured scattering cross section of $\mathrm{rBC}$-containing particles was consistent with that based on the Mie-scattering simulation. We found that only $28 \%$ of the rBC-containing particles were in coreshell structures with a particle mass of $10 \mathrm{fg}$ in the clean period but that proportion increased considerably, to $45 \%$, in the polluted period. Due to the morphology change, the absorption enhancement $\left(E_{\mathrm{abs}}\right)$ was $12 \%$ lower than that predicted for core-shell structures.

\section{Introduction}

Black carbon (BC) aerosol is one of the principal lightabsorbing aerosols in the atmosphere. BC is regarded as one of the most important components contributing to global warming (Bond et al., 2013). BC has a much shorter lifetime than $\mathrm{CO}_{2}$. Thus, BC's radiative perturbation on a regional scale may be different from globally averaged estimates. It has been reported that BC's direct radiative forcing can reach an order of $\geq 10 \mathrm{~W} \mathrm{~m}^{-2}$ over eastern and southern Asia (Bond et al., 2013). BC aerosols can also influence the climate by altering cloud properties, such as the evaporation of cloud droplets, cloud lifetime and albedo ( $\mathrm{Ra}$ manathan et al., 2001; Ramanathan and Carmichael, 2008). 
Ding et al. (2016) determined that the existence of BC in the upper mixing layer could absorb downward solar radiation, impeding the development of the boundary layer, which aggravates air pollution. Moreover, BC aerosols have detrimental health effects. Black carbon and organic carbon are regarded as the most toxic pollutants in $\mathrm{PM}_{2.5}$ and lead to as many as $\sim 3$ million premature deaths worldwide (Adler et al., 2010; Apte et al., 2015).

Black carbon is typically emitted from the incomplete combustion of fossil fuels and biomass. After being emitted into the atmosphere, $\mathrm{BC}$ particles tend to mix with other substances through coagulation, condensation and other photochemical processes that significantly change BC's cloud condensation nuclei activity as well as its light absorption ability (Bond et al., 2013; Liu et al., 2013). The model results suggest that after BC's core is surrounded by a well-mixed shell, its direct-absorption radiative forcing could be $50 \%$ higher than that of BC in an external mixing structure (Jacobson, 2001). Such an absorption enhancement phenomenon is interpreted as exhibiting a "lensing effect", in which a nonabsorbing coating causes more radiation to interact with the $\mathrm{BC}$ core and thus more light is absorbed. This absorption enhancement effect has been proven in laboratory studies (Schnaiter et al., 2005). Shiraiwa et al. (2010) reported that the absorption enhancement of BC in a core-shell structure increased with coating thickness and reached a factor as high as 2. Nevertheless, field observation results demonstrated large discrepancies (6\% to $40 \%$ ) in the absorption enhancement of aged BC particles (Cappa et al., 2012; Lack et al., 2012). The discrepancies could be attributed to the complex mixing state of $\mathrm{BC}$ in the real atmosphere, which depends on the coating composition, the coating amount, and the size of the BC core and structure. Bond et al. (2013) regarded the mixing state of $\mathrm{BC}$ as one of the most important uncertainties in evaluating BC direct radiative forcing. Furthermore, freshly emitted $\mathrm{BC}$ is initially hydrophobic. Mixing $\mathrm{BC}$ with other soluble materials will significantly increase BC-containing particles' hygroscopicity and thus their ability to become cloud condensation nuclei (Bond et al., 2013; Popovicheva et al., 2011). This ability is associated with the wet deposition rate and consequently influences the lifetime and spatial distribution of $\mathrm{BC}$ particles in the atmosphere. For these reasons, more observations are needed to determine the specific spatial and temporal distribution of BC's mixing state, which would be helpful for minimizing the uncertainty in evaluating BC's climatic and environmental effects.

China's economy has grown rapidly in recent decades, accompanied by the substantial emission of pollutant precursors. Annual emissions of $\mathrm{BC}$ in China are reported to have increased from $0.87 \mathrm{Tg}$ in 1980 to $1.88 \mathrm{Tg}$ in 2009 , comprising half of the total emissions in Asia and an average of $18.97 \%$ of the global BC emissions during this period (Qin and Xie, 2012). Such substantial BC emissions greatly influence the regional climate and environment (Ding et al., 2016; Menon et al., 2002). Although spatio-temporal variations in
$\mathrm{BC}$ and the corresponding optical properties of aged $\mathrm{BC}$ have been recently reported (Cao et al., 2004, 2007; Zhang et al., 2009), the number of observational studies on BC's mixing state remains insufficient. Recently, the single-particle soot photometer (SP2) has been used as a reliable instrument for estimating the mixing state of $\mathrm{BC}$ due to its singleparticle resolution and high accuracy. Several studies have used SP2 to investigate BC's mixing state in China (Gong et al., 2016; Huang et al., 2012; Wang et al., 2016; Wu et al., 2017). Most studies have primarily focused on the variability in BC's mixing state on severe haze days during winter because of the extremely high concentrations of particle matter and low visibility. In summer, higher radiation and high hydroxyl radical concentrations favor photochemical reactions and thus contribute to the condensation aging of BC. By using a smog chamber, Peng et al. (2016) found that the amount of BC-containing particles increased rapidly, owing to the photochemical aging of the $\mathrm{BC}$-coating materials from Beijing's urban environment, even in relatively clean conditions. Cheng et al. (2012) noted that the changing rate of BC from an external to internal mixing state can reach up to $20 \% \mathrm{~h}^{-1}$ in summer. Thus, the mixing state of $\mathrm{BC}$ should also be carefully considered on relatively clean days during summer.

In this study, we used an SP2 to investigate BC in the urban areas of Beijing, China, during early summer, focusing on the size distribution and coating thickness of $\mathrm{BC}$-containing particles. Field experiments using a tandem system consisting of a centrifugal particle mass analyzer (CPMA; Cambustion Ltd.) and a differential mobility analyzer (DMA; model 3085A, TSI Inc., USA) with an SP2 were performed during two during clean and polluted cases, focusing on BCcontaining particles' microphysical properties, including the effective density, morphology and light absorption enhancement. The results of this paper were exhibited in the following sequence: (1) the size distribution of $\mathrm{BC}$ core and its influence factors such as seasons, weather conditions, etc.; (2) the coating thickness of BC and its influence factors such as diurnal variation, $\mathrm{O}_{x}$ condition, etc.; (3) the morphology of $\mathrm{BC}$ and its relationship with coating thickness; and (4) the relationship of morphology of BC with its light absorption. Various techniques have been developed to quantify the mass concentration of $\mathrm{BC}$ aerosols, including optical, thermal, thermal-optical and photoacoustic methods. For the SP2, the mass concentration of BC was measured on the basis of incandescent signal emissions; therefore, refractory black carbon (rBC) was used. The abbreviations and symbols used in this paper are listed in Table S1 in the Supplement.

\section{Observation and methodology}

\subsection{Site description}

The measurement of $\mathrm{rBC}$ particles was performed from 30 May to 13 June 2018 in an air-conditioned container lo- 
cated on the tower campus of the State Key Laboratory of Atmospheric Boundary Layer Physics and Atmospheric Chemistry (LAPC), Institute of Atmospheric Physics $\left(39.97^{\circ} \mathrm{N}\right.$, $\left.116.37^{\circ} \mathrm{E}\right)$. The sampling site is located between the northern 3rd and 4th Ring Road of Beijing, approximately $50 \mathrm{~m}$ from the closest road and $380 \mathrm{~m}$ away from the nearest highway (the Jingzang highway) (Fig. 1b). Anthropogenic emissions from the experimental campus were negligible. Thus, this site can represent the urban conditions in Beijing well.

\subsection{Single-particle soot photometer (SP2)}

A single-particle soot photometer (SP2, Droplet Measurement Technologies, Inc., Boulder, CO, USA) was used to determine the size distribution and mixing state of $\mathrm{rBC}$ particles in the atmosphere. In the SP2 measuring chamber, an intense continuous intracavity $\mathrm{Nd}$ : YAG laser beam is generated (1064 nm, TEM00 mode). After an rBC-containing particle crosses the beam, it is heated to incandesce by sequentially absorbing the laser power. The maximum incandescence intensity (or the peak height of the incandescence signal) is approximately linearly correlated with rBC mass, irrespective of the presence of non-BC material or the rBC's morphology. The SP2 was calibrated to determine the relationship between the incandescence peak height and the mass of rBC particles using Aquadag aerosols (Acheson Inc., USA). Figure $2 b$ illustrates the schematic diagram of the calibration system. During calibration, monodisperse Aquadag aerosols were generated with an atomizer (model 3072, TSI Inc., USA) and dried using a diffusion dryer. Then, Aquadag aerosols with known mass $\left(M_{\mathrm{rBC}}\right)$ were selected with a CPMA and injected into the SP2 to obtain the corresponding laser-induced incandescence (LII) signal. A recent study (Laborde et al., 2012) demonstrated that the mass of rBC particles could be underestimated when using Aquadag aerosol as the calibration material. We performed a correction by multiplying by a factor of 0.75 for LII peak height during the calibration, as described in Zhang et al. (2018) and Liu et al. (2014). The LII peak- $M_{\mathrm{rBC}}$ relationship was thus obtained (Fig. S1 in the Supplement). The uncertainty of the derived $\mathrm{rBC}$ mass was estimated to be $20 \%$, which corresponds to an uncertainty of $\sim 6 \%$ of the mass equivalent size $\left(D_{\mathrm{c}}\right)$,

$D_{\mathrm{c}}=\sqrt[3]{\frac{6 \times M_{\mathrm{rBC}}}{\pi \times \rho_{\mathrm{rBC}}}}$,

by using a $1.8 \mathrm{~g} \mathrm{~cm}^{-3}$ density for $\mathrm{rBC}$ material density (Bond et al., 2013).

In addition to the incandescence channel, SP2 also has scattering channels to directly measure the scattering cross section $\left(\sigma_{\text {measured }}\right)$ of every single particle. However, for $\mathrm{rBC}$ containing particles, the particles will evaporate during the measurement, since rBC can absorb the laser energy, which results in a decrease in the rBC-containing particles' sizes and thus a decrease in the $\sigma_{\text {measured. The leading-edge-only }}$
(LEO) fitting method was invented to obtain the scattering cross section of the initial $\mathrm{rBC}$-containing particles before evaporation (Gao et al., 2007). With $\sigma_{\text {measured }}$ and $D_{\mathrm{c}}$, the diameter $\left(D_{\mathrm{p}}\right)$ of the rBC-containing particle can be obtained using Mie theory with refractive indices of 2.26-1.26i for the rBC (Moteki et al., 2010) and 1.48-0i for the coatings (Taylor et al., 2015) by assuming a core-shell structure. Thus, the coating thickness of $\mathrm{rBC}$ can be directly determined by $\mathrm{SP} 2$, as denoted by the shell-core ratio $\left(D_{\mathrm{p}} / D_{\mathrm{c}}\right)$. The $D_{\mathrm{p}}$ derivation method based on LEO fitting has been widely used (Taylor et al., 2015; Shiraiwa et al., 2008; Liu et al., 2014; Laborde et al., 2013), and Liu et al. (2015) estimated that the core-shell assumption will cause $<6 \%$ uncertainty in the derived $D_{\mathrm{p}} / D_{\mathrm{c}}$. The scattering signal of SP2 was calibrated using polystyrene latex spheres (PSL, Nanosphere Size Standards, Duke Scientific Corp., USA) with known sizes ( $203 \pm 3 \mathrm{~nm}$ : lot no. $185856 ; 303 \pm 3 \mathrm{~nm}$ : lot no. 189903 ; $400 \pm 3$ nm: lot no. 189904), as shown in Fig. S2. The calibration of the scattering channel and the incandescence channel was also conducted after the observation. The calibration coefficient varied little $(<3 \%)$, and the YAG power (laser intensity index recorded by the SP2) fluctuated by $4.8 \pm 0.1$, indicating the stable condition of the SP2 during the observation period.

The detection efficiency of the SP2 was determined by comparing the number concentrations of Aquadag as simultaneously measured by the SP2 and a condensation particle counter (CPC; model 3775, TSI Inc., USA). For large particles, the SP2 detection efficiency was approximately unity and decreased gradually for smaller rBC particles (Fig. S3). For rBC with $D_{\mathrm{c}}<70 \mathrm{~nm}$, the detection efficiency of the SP2 fell significantly below $60 \%$. The mass concentrations of rBC may be underestimated because of the low detection efficiency of for smaller rBC particles. By extrapolating a lognormal function fit to the observed mass distribution, we found that $\mathrm{rBC}$ particles outside the detection range caused an $\sim 15 \%$ underestimation of the $\mathrm{rBC}$ mass concentration. To compensate, the mass concentration of $\mathrm{rBC}$ was corrected by dividing by a factor of 0.85 during the measurement.

In general, the SP2 can directly measure the mass of the $\operatorname{rBC}$ core $\left(M_{\mathrm{rBC}}\right)$ and thus the mass equivalent diameter $\left(D_{\mathrm{c}}\right)$. Additionally, the scattering cross section ( $\left.\sigma_{\text {measured }}\right)$ can be directly obtained by the SP2, and the diameter of the rBCcontaining particle $\left(D_{\mathrm{p}}\right)$ can be derived using Mie theory.

\subsection{Experiment}

Two kinds of measurements were conducted in this study: a regular single-SP2 observation to provide the number and mass size distribution and coating thickness of the rBCcontaining particles and a tandem CPMA-SP2-DMA-SP2 experiment to study the microphysical properties of the $\mathrm{rBC}$ containing particles. 

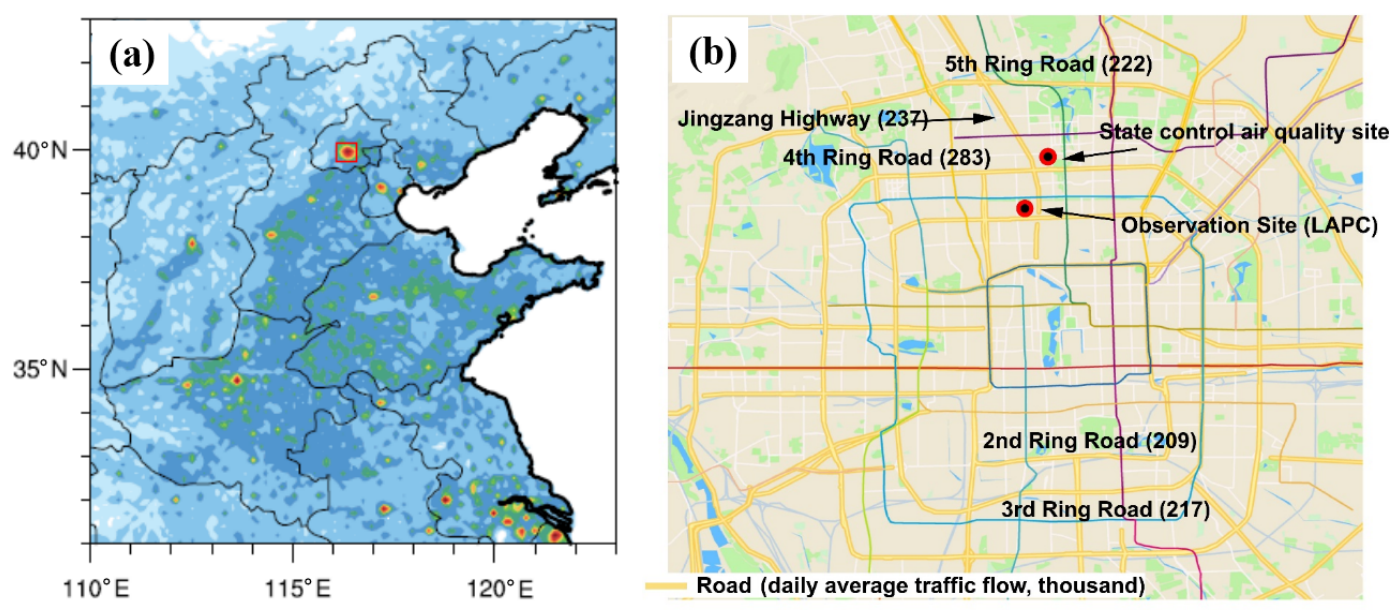

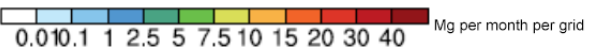

Figure 1. (a) Monthly emissions of BC from traffic in June in eastern-central China. The red box denotes the geographical location of the observation site; the map was taken from NCL software (@2019 NCL, https://www.ncl.ucar.edu, last access: 28 March 2019). (b) Road map and traffic flow rate of Beijing. The red circle denotes the observation site; the map was taken from Google Maps (CGoogle Maps 2019, https://www.google.com/maps, last access: 15 January 2019).

\subsubsection{Single-SP2 measurement}

The regular single-SP2 observations were conducted from 30 May to 7 June and 9 to 12 June. An aerosol sampling inlet was placed at $4 \mathrm{~m}$ a.g.l. (meters above ground level). A PM 2.5 cyclone (URG-2000-30ENS-1) was used to selectively measure particles with an aerodynamic diameter smaller than $2.5 \mu \mathrm{m}$ because $\mathrm{rBC}$ particles are typically present in the submicron mode. The systematic configuration of the rBC measurements is presented in Fig. 2a. A supporting pump with a flow rate of $9.6 \mathrm{~L} \mathrm{~min}^{-1}$ was used to guarantee a total inlet flow rate of $10 \mathrm{~L} \mathrm{~min}^{-1}$ (the demanding flow rate of a $\mathrm{PM}_{2.5}$ cyclone) and to minimize particle loss in the tube. The residence time of the sampling flow was estimated to be $\sim 17 \mathrm{~s}$. Then, the sample air was dried by passing through a Nafion dryer (MD-700-24S, TSI) at a flow rate of $0.4 \mathrm{~L} \mathrm{~min}^{-1}$. The dried sample was measured with the SP2 and CPC.

\subsubsection{Tandem CPMA-SP2-DMA-SP2 measurement}

The tandem CPMA-SP2-DMA-SP2 experiments were conducted on 8 and 13 June: 8 June is representative of a clean period, when the concentrations of $\mathrm{PM}_{2.5}$ and $\mathrm{O}_{3}$ averaged $20 \mu \mathrm{g} \mathrm{m}^{-3}$ and $60 \mathrm{ppbv}$, respectively, and Beijing was mainly affected by a clean northern air mass (Fig. S5), while 13 June is representative of a polluted period when the hourly mass concentration of $\mathrm{PM}_{2.5}$ exceeded $110 \mu \mathrm{g} \mathrm{m}^{-3}$ - the air mass was from the southern area of Beijing, which is one of the most polluted areas in China. Thus, the tandem CPMA-SP2DMA-SP2 experiment was conducted on 8 and 13 June to study the detailed physical characteristics of $\mathrm{rBC}$ under different pollution conditions.

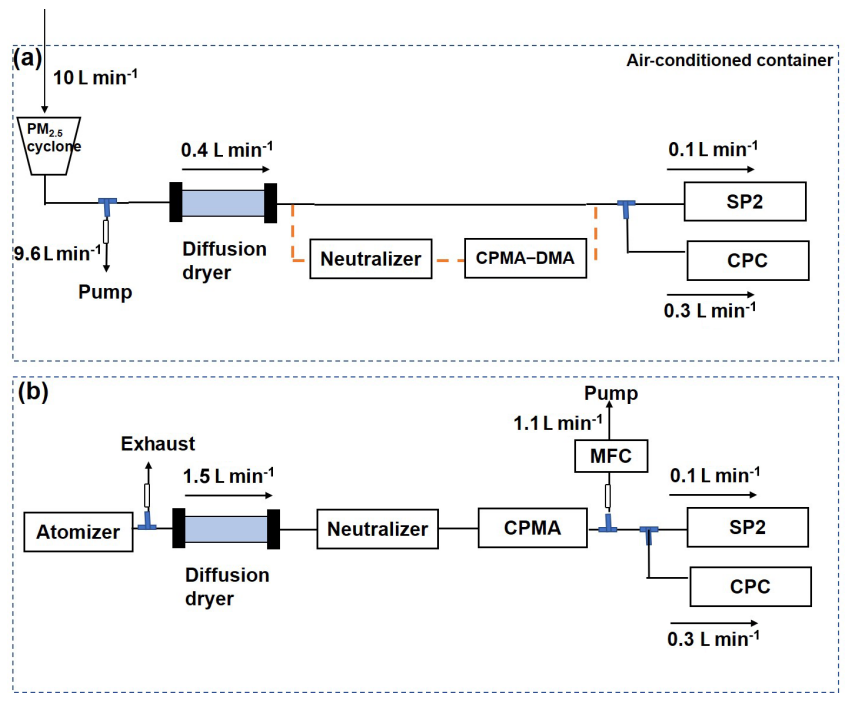

Figure 2. Schematic diagram of (a) the measurement system, with the orange dashed line denoting the tandem CPMA-SP2-DMA-SP2 measurement system, during the periods 9 and 13 June, and (b) the calibration system.

As shown in Fig. 2a, the tandem system was similar to the regular single-SP2 observation system. The difference is the neutralizer, and a DMA or CPMA was added in front of the SP2, as denoted by the orange dashed line. Specifically, in the DMA-SP2 system, particles were first selected by DMA to obtain particles with known mobility diameters $\left(D_{\mathrm{mob}}\right)$. Then, the monodispersed particles were injected into the SP2 to obtain the corresponding information. In practice, we set three $D_{\text {mob }}$ points $\left(D_{\text {mob }}=200,250,300 \mathrm{~nm}\right)$. The 
duration of one set point is $\sim 20 \mathrm{~min}$, and we recorded data 2 min after we changed the set point to allow the system to stabilize. The purpose of the DMA-SP2 system is to obtain the effective density of bare $\mathrm{rBC}$. Bare $\mathrm{rBC}$ is defined as $\mathrm{rBC}$ with $D_{\mathrm{p}} / D_{\mathrm{c}} \approx 1.0$, and the effective density of bare $\mathrm{rBC}$ was calculated according to the following equation:

$\rho_{\mathrm{eff}}=\frac{6 M_{\mathrm{rBC}}}{\pi D_{\mathrm{mob}}^{3}}$.

In principle, the measured effective density is the same as the material density if the particle has an ideal spherical shape with no void space. Thus, the effective density is an indicator of particle compactness, as it compares the effective density and the material density. Several studies that include the coupling of DMA with an aerosol particle mass analyzer (APM) or CPMA have been conducted to determine the $\rho_{\text {eff }}-D_{\text {mob }}$ relationship of Aquadag rBC samples in the laboratory (Moteki and Kondo, 2010; Gysel et al., 2011). The relationship between the $\rho_{\text {eff }}$ and $D_{\text {mob }}$ of Aquadag is presented in Fig. S4. The $\rho_{\text {eff }}$ obtained using the DMA-SP2 system in this study agreed well with previous research.

In the CPMA-SP2 system, particles with known mass $\left(M_{\mathrm{p}}\right)$ selected by CPMA were injected into the SP2, and the $M_{\mathrm{p}}$ set points were $1,2,5$ and $10 \mathrm{fg}$. The duration of one set point was $\sim 20 \mathrm{~min}$, and we waited $2 \mathrm{~min}$ after we changed the set points to record a measurement. The purpose of the CPMA-SP2 system is to obtain morphological information about rBC-containing particles with different coating degrees. Using a tandem CPMA-SP2 system, the mass of an rBC-containing particle $\left(M_{\mathrm{p}}\right)$ and of the $\mathrm{rBC}$ core $\left(M_{\mathrm{rBC}}\right)$ can be simultaneously obtained. The coating thickness can be represented by the mass ratio of the coating to the $\mathrm{rBC}$ core $\left(M_{\mathrm{R}}=\left(M_{\mathrm{p}}-M_{\mathrm{rBC}}\right) / M_{\mathrm{rBC}}\right)$ without any assumptions. Knowing $M_{\mathrm{p}}$ and $M_{\mathrm{rBC}}$, the scattering cross section of rBC-containing particles can be calculated through Mie theory with refractive indices of 2.26-1.26i for the $\mathrm{rBC}$ and $1.48 i$ for the coatings by assuming a core-shell structure and a coating density of $1.5 \mathrm{~g} \mathrm{~cm}^{-3}$. The calculated scattering cross section $\left(\sigma_{\text {model }}\right)$ can be compared to the $\sigma_{\text {measured }}$ by SP2, which can reflect the morphological characteristic of rBC-containing particles; this comparison will be further discussed in Sect. 4.1.2.

\subsection{Results}

\subsection{Concentrations of $\mathrm{PM}_{2.5}, \mathrm{rBC}$ and pollutant gases}

The temporal variations in the concentrations of $\mathrm{PM}_{2.5}, \mathrm{rBC}$ and gaseous pollutants $\left(\mathrm{O}_{3}, \mathrm{NO}_{2}\right)$ during the project are presented in Fig. 3. The regular pollutant concentrations, including $\mathrm{PM}_{2.5}$ (1405-F, Thermo Fisher Scientific), $\mathrm{NO}_{2}$ (42c, Thermo Fisher Scientific) and $\mathrm{O}_{3}$ (49i, Thermo Fisher Scientific), were obtained from a state-controlled air quality site ( $2.5 \mathrm{~km}$ from LAPC), provided by the China National Environmental Monitoring Center. The mass concentration of
$\mathrm{PM}_{2.5}$ ranged between 5 and $120 \mu \mathrm{g} \mathrm{m}^{-3}$ on a daily basis during the observation period. The mixing ratios of both $\mathrm{NO}_{2}$ and $\mathrm{O}_{3}$ exhibited obvious opposite diurnal variations. The maximum $\mathrm{O}_{3}$ concentration appeared at 14:00 LST on 2 June, with a value of $145 \mathrm{ppbv}$, reflecting high atmospheric oxidant levels and strong photochemistry during the observation period. The mass concentration of $\mathrm{rBC}$ was $1.2 \pm$ $0.7 \mu \mathrm{g} \mathrm{m}^{-3}$ on average, accounting for $3.5 \pm 2.4 \%$ of $\mathrm{PM}_{2.5}$ on an hourly basis, which was comparable to the previous filter-based measurement in Beijing, with an average fraction of $3.2 \%$ in the summer of 2010 (Zhang et al., 2013). The mass concentration of $\mathrm{rBC}$ also exhibited a clear diurnal variation, with a maximum at night and a minimum at noon.

During the period from 1 to 6 June, the meteorological conditions were characterized by low relative humidity $(\mathrm{RH}<40 \%)$ and strong solar radiation and were favorable for ozone formation. The mixing ratio of ozone was relatively high from 1 to 6 June. On 7 June, a heavy rainfall event occurred, and most of the major pollutants decreased due to significant wet scavenging. The mass concentration of $\mathrm{PM}_{2.5}$ decreased from 65 to $10 \mu \mathrm{g} \mathrm{m}^{-3}$, and the mass concentration of rBC decreased from 2.6 to $0.2 \mu \mathrm{g} \mathrm{m}^{-3}$ from 03:00 to 07:00 LST on 7 June. The pollutant concentration remained at a low level from 7 to 8 June. After 9 June, the ambient RH increased to $80 \%$. Under high-humidity conditions, the mass concentration of $\mathrm{PM}_{2.5}$ experienced steady growth, increasing from 10 to $120 \mu \mathrm{g} \mathrm{m}^{-3}$ and staying at a high level from 12 to 13 June. Thus, the tandem CPMA-SP2-DMA-SP2 observations were conducted separately on 8 and 13 June, which separately represented the different $\mathrm{PM}_{2.5}$ pollution conditions.

\subsection{Size distribution of $\mathrm{rBC}$}

The number and mass distribution as a function of the $D_{\mathrm{c}}$ are illustrated in Fig. 4. As presented, the number size distribution follows the lognormal distribution and peaks at $70 \mathrm{~nm}$; the mass size distribution is also fitted by the lognormal distribution, and the mass median diameter (MMD) was $171 \mathrm{~nm}$ during the project. A brief summary of the SP2 observations in China is presented in Table 1. Most previous studies focused on the rBC characteristics in winter, when a larger MMD ( 200-230 nm) was obtained (Zhang et al., 2013; Wu et al., 2017; Wang et al., 2016; Huang et al., 2012; Gong et al., 2016) than in this study. A similar MMD (180 nm) was reported in urban Shenzhen during a summer observation period (Lan et al., 2013), and a higher MMD (210$222 \mathrm{~nm}$ ) was reported in winter. Liu et al. (2014) also found a winter-high-summer-low trend for $\mathrm{rBC}$ sizes in London, with $D_{\mathrm{c}}=149 \pm 22 \mathrm{~nm}$ in winter and $120 \pm 6 \mathrm{~nm}$ in summer. Laboratory studies have proven that MMD is highly dependent on combustion conditions (Pan et al., 2017) and material. Thus, MMD is a suitable indicator of the sources of rBC. Several studies have suggested that the MMD of rBC from biomass burning and coal is much larger than that from 


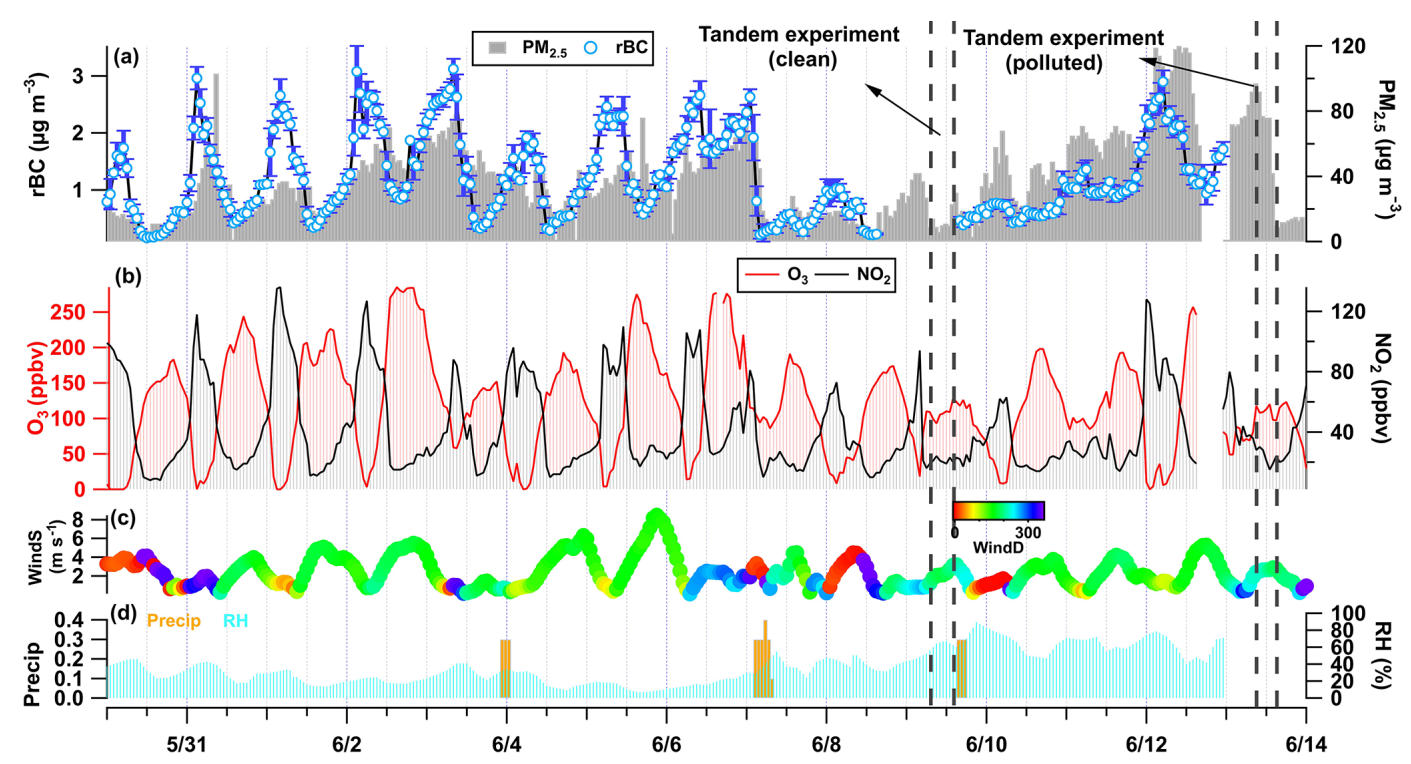

Figure 3. Time series of aerosol/gaseous pollutants and meteorological conditions during the observation period.

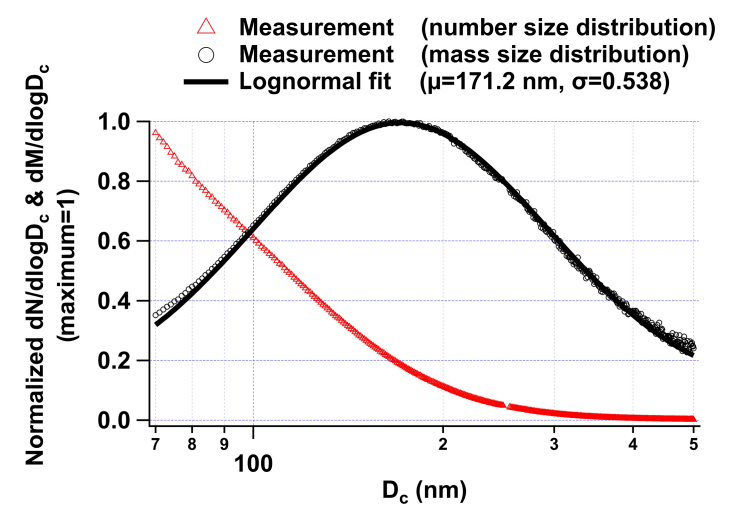

Figure 4. Number and mass size distribution $\left(\mathrm{d} N / \mathrm{d} \log D_{\mathrm{c}}\right.$ and $\left.\mathrm{d} M / \operatorname{d} \log D_{\mathrm{c}}\right)$ during the observation period.

traffic emissions (Wang et al., 2016; Schwarz et al., 2008). Huang et al. (2012) found the MMD observed at rural sites to be much larger than that observed at urban sites because urban sites are primarily affected by $\mathrm{rBC}$ emitted from traffic sources and rural sites are more influenced by $\mathrm{rBC}$ from coal combustion. The seasonal trends in MMD may be partially explained by the different $\mathrm{rBC}$ sources in summer and winter.

Figure 5 provides the temporal variations in the mass size distribution of $\mathrm{rBC}$ during the entire investigation period. Most $\mathrm{rBC}$ particles were within the size range of $70-300 \mathrm{~nm}$, with a clear diurnal pattern of the value of $\mathrm{d} M / \mathrm{d} \log D_{\mathrm{c}}$. The diurnal cycle reached a peak plateau between 03:00 and 07:00 LST and decreased gradually in the afternoon. The cycle was controlled by the combined effects of the development of planetary boundary layer (PBL) variation and onroad $\mathrm{rBC}$ emissions.
After the two rain events (4 and 7 June), the MMD decreased significantly from 186 to $170 \mathrm{~nm}$ and from 183 to $159 \mathrm{~nm}$, respectively, as shown in Figs. 3 and S7. Taylor et al. (2014) observed that the rBC core size distribution shifted to smaller sizes after a biomass-burning plume passed through a precipitating cloud, attributing this shift to the preferential nucleation scavenging of larger $\mathrm{rBC}$ cores. By counting the MMD on non-rainy days and rainy days, Wang et al. (2018) also found that the MMD decreased from $164 \pm 21$ to $145 \pm 25 \mathrm{~nm}$. The decrease in MMD after rain events can be explained by the preferential wet scavenging of the larger rBC-containing particles.

A pollutant rose plot of MMD versus wind speed and wind direction is presented in Fig. 6a. The MMD of $\mathrm{rBC}$ was $\sim 160 \mathrm{~nm}$ at low-wind-speed conditions and exhibited a significant increase with increasing southeastern wind speed. The maximum MMD exceeded $190 \mathrm{~nm}$ when the wind speed was greater than $10 \mathrm{~m} \mathrm{~s}^{-1}$. Figure $6 \mathrm{~b}$ presents the correlation between wind speed and MMD. A southerly wind period was selected when the wind direction was $135-225^{\circ}$, and a northerly wind period was the time when the wind direction was $325-45^{\circ}$. The MMD exhibited little correlation with wind speed and varied little between the southern and northerly wind periods when the wind speeds were less than $2 \mathrm{~m} \mathrm{~s}^{-1}$, as local $\mathrm{rBC}$ emissions were predominant. An MMD of $150-160 \mathrm{~nm}$ during low-wind-speed periods may be characteristic of the local sources. The MMD had a strong positive correlation with the wind speed during the southerly wind period $\left(r^{2}=0.93\right)$, suggesting that the $\mathrm{rBC}$ from the south was larger, which may be the result of the different rBC sources in the southern polluted region. Since the air mass from the north is always clean, the local rBC emissions may be the main contributors to the total $\mathrm{rBC}$ concentration 


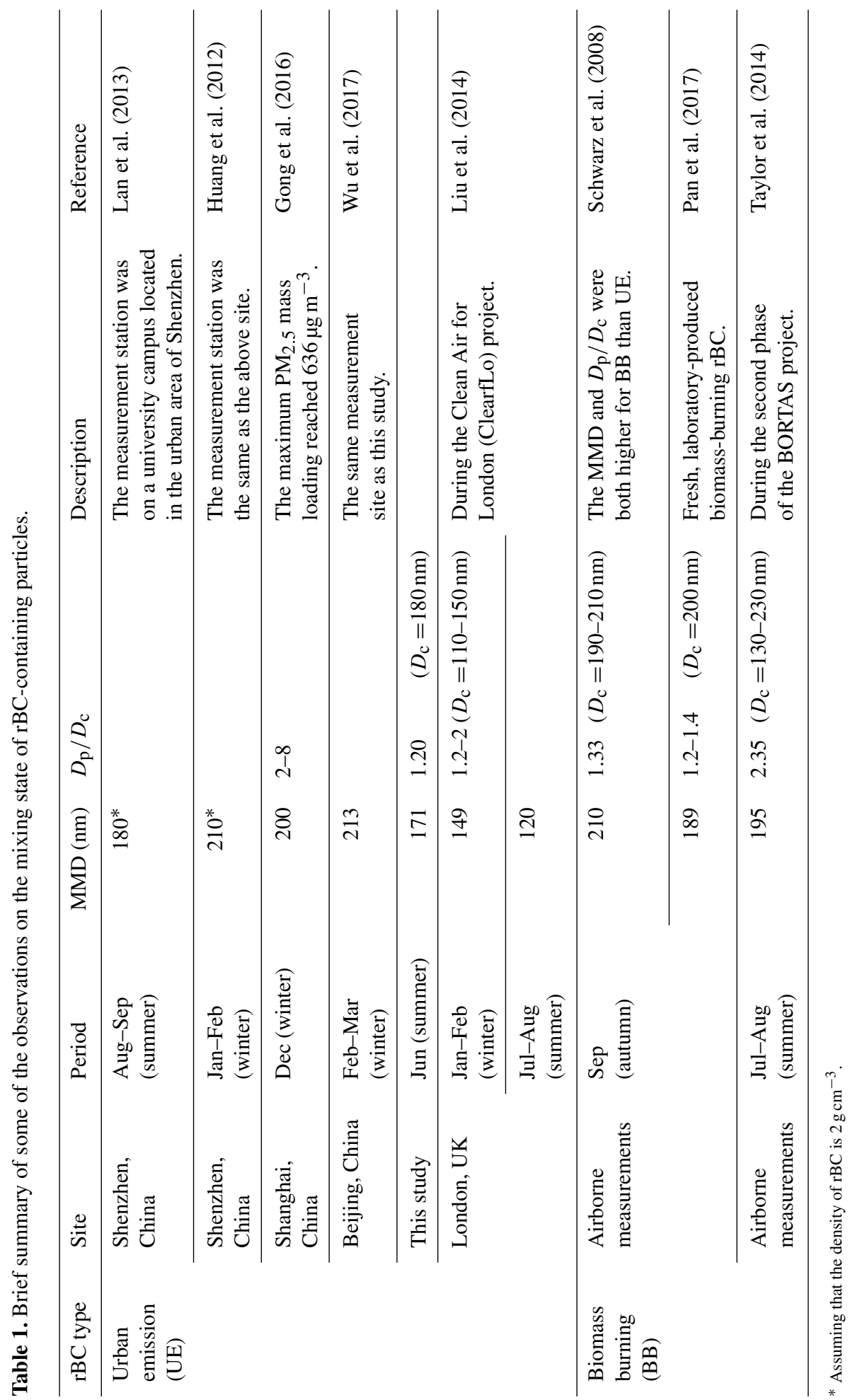




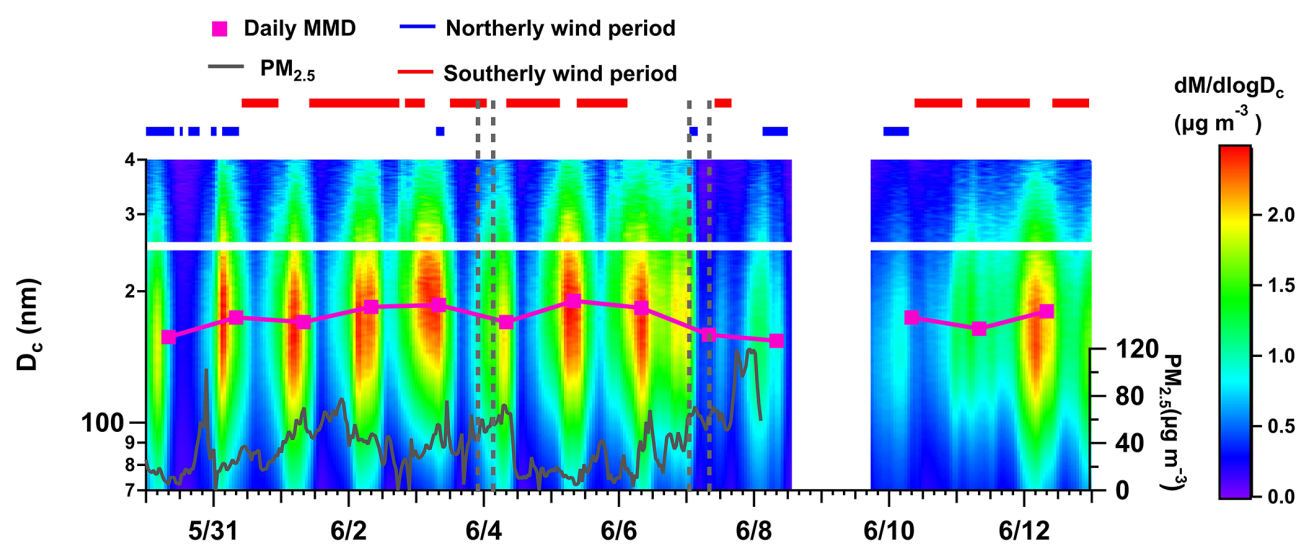

Figure 5. Time series of the mass size distribution of $\mathrm{rBC}$. A southerly wind period is selected when the wind direction is $135-225^{\circ}$, and a northerly wind period is the time when the wind direction is $325-45^{\circ}$. The gray dashed line denotes the rainy period.

(a)

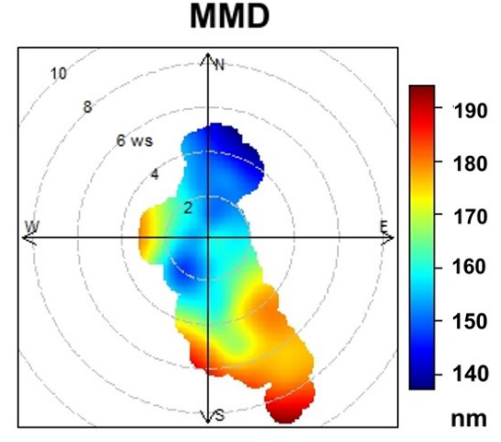

(b)

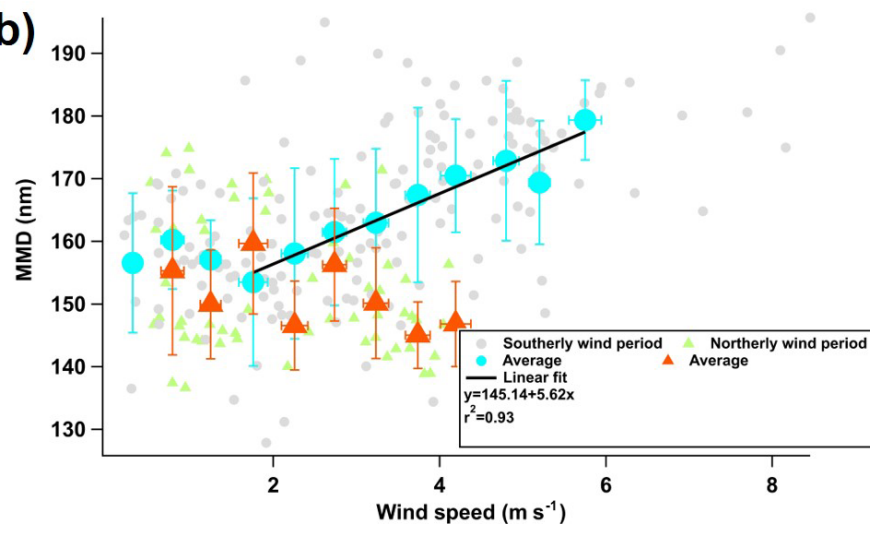

Figure 6. (a) Dependence of rBC's MMD on wind speed and wind direction during the observation period. (b) MMD versus wind speed during the southerly wind period and northerly wind period. The error bars correspond to the standard deviations of MMD in each wind speed bin.

in the northerly wind period. Thus, the MMD may be more influenced by local emissions and show a weak correlation with the wind speed during northerly wind periods.

\subsection{Temporal variation in $D_{\mathrm{p}} / D_{\mathrm{c}}$}

The $D_{\mathrm{p}} / D_{\mathrm{c}}$ for a given single $\mathrm{rBC}$-containing particle was calculated using the LEO fitting method. Herein, $\mathrm{rBC}$ cores with $D_{\mathrm{c}}=180 \pm 10 \mathrm{~nm}$ were selected because the low scattering signal of small $\mathrm{rBC}$ is easily influenced by signal noise ( $D_{\mathrm{p}} / D_{\mathrm{c}}$ indicates the $D_{\mathrm{p}} / D_{\mathrm{c}}$ with $D_{\mathrm{c}}=180 \pm 10 \mathrm{~nm}$ in the following discussion if not specified). The $D_{\mathrm{p}} / D_{\mathrm{c}}$ variation during the investigation period is illustrated in Fig. 7. In general, $D_{\mathrm{p}} / D_{\mathrm{c}}$ was $1.20 \pm 0.05$ on average during the investigation, which is consistent with observations (1.15) during the summer in Paris (Laborde et al., 2013). Black carbon sources and the aging process significantly influenced the $D_{\mathrm{p}} / D_{\mathrm{c}}$ of $\mathrm{rBC}$. The $\mathrm{rBC}$ from traffic is reported to be relatively uncoated (Liu et al., 2014), whereas the rBC emitted by biomass burning is found to be moderately coated, with
$D_{\mathrm{p}} / D_{\mathrm{c}}=1.20-1.40$ (Pan et al., 2017). Moreover, $D_{\mathrm{p}} / D_{\mathrm{c}}$ increases with the aging process, and a larger $D_{\mathrm{p}} / D_{\mathrm{c}}(1.60)$ was found in an aged continental air mass (Shiraiwa et al., 2008). The relatively low $D_{\mathrm{p}} / D_{\mathrm{c}}$ value further supports the argument that $\mathrm{rBC}$ was primarily emitted from on-road vehicles during the summer in Beijing.

The $D_{\mathrm{p}} / D_{\mathrm{c}}$ distributions for the two episodes before the tandem CPMA-SP2-DMA-SP2 experiments are shown in Fig. 7. Episode 1 (7 June at 22:00 LST-8 June at 12:00 LST) occurred after a heavy rain period and is representative of clean conditions. Episode 2 (11 June at 23:00 LST-12 June at 12:00 LST) was characterized by the highest average $D_{\mathrm{p}} / D_{\mathrm{c}}$ value (1.40) and the highest $\mathrm{PM}_{2.5}$ concentration value $\left(120 \mu \mathrm{g} \mathrm{m}^{-3}\right)$ during the observation period. The $D_{\mathrm{p}} / D_{\mathrm{c}}$ exhibited a unimodal distribution during episode 1 (Fig. 7b) and a clear bimodal pattern during episode 2 (Fig. 7c), which indicates that there may be one type of $\mathrm{rBC}$ in episode 1 and two types of $\mathrm{rBC}$ with a clear coating thickness difference in episode 2. The coating thickness of the first kind of $\mathrm{rBC}$ was relatively thin, with a $D_{\mathrm{p}} / D_{\mathrm{c}}$ value of $\sim 1.05$, corresponding 


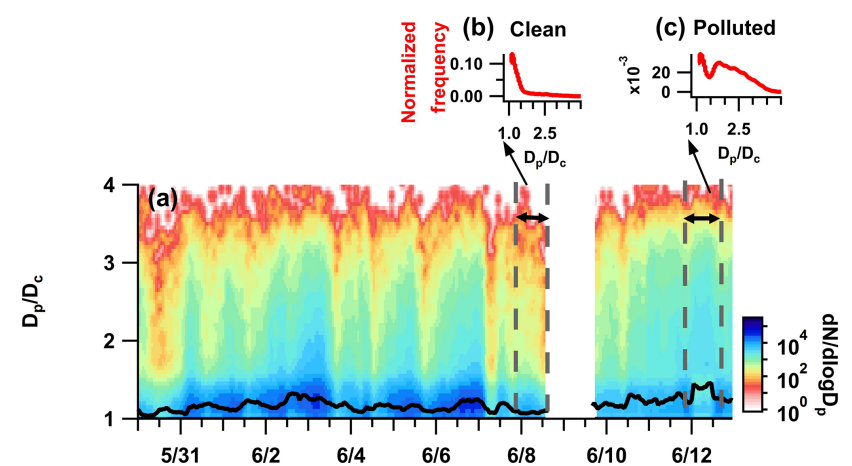

Figure 7. (a) Temporal variation in $D_{\mathrm{p}} / D_{\mathrm{c}}$, with $D_{\mathrm{c}}=180 \mathrm{~nm}$; the image plot denotes the frequency $\left(\mathrm{d} N / \mathrm{d} \log D_{\mathrm{p}}\right)$ of $\mathrm{rBC}$-containing particles with varied $D_{\mathrm{p}} / D_{\mathrm{c}}$ values. The black line denotes the average $D_{\mathrm{p}} / D_{\mathrm{c}}$ for each hour. (b) The normalized frequency of $D_{\mathrm{p}} / D_{\mathrm{c}}$ for the clean period before the tandem experiment. (c) The normalized frequency of $D_{\mathrm{p}} / D_{\mathrm{c}}$ for the polluted period.

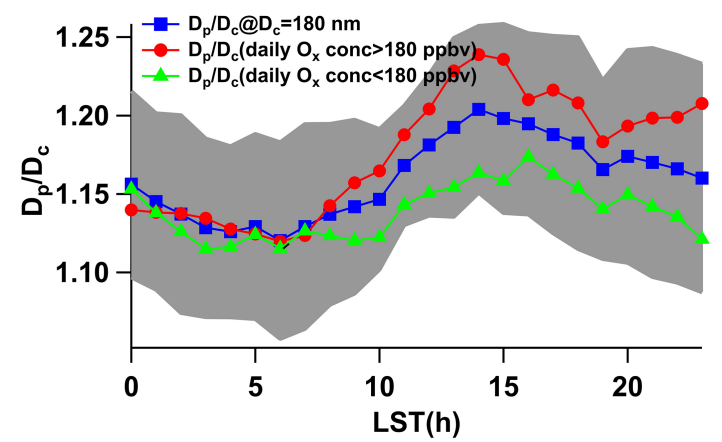

Figure 8. Diurnal variation in $D_{\mathrm{p}} / D_{\mathrm{c}}$ for all periods, high- $\mathrm{O}_{x}$ periods and low- $\mathrm{O}_{x}$ periods. The gray shaded area denotes the standard deviation of $D_{\mathrm{p}} / D_{\mathrm{c}}$ for all periods.

to the single peak of the unimodal distribution in episode 1 and the left peak of the unimodal distribution. This kind $\mathrm{rBC}$ may be freshly emitted by the local $\mathrm{rBC}$ sources (such as traffic) and underwent a short aging time. However, the second kind of $\mathrm{rBC}$ was thickly coated, with a $D_{\mathrm{p}} / D_{\mathrm{c}}$ value of $\sim 1.80$, corresponding to the right peak of the bimodal distribution during episode 2. Zhang et al. (2018) demonstrated that $63 \%$ of the rBC was estimated to be transported from outside of Beijing during previous pollution events, and the rBC-containing particles from regional transportation were characterized by having more coating material. The rBCcontaining particles with $D_{\mathrm{p}} / D_{\mathrm{c}}=1.80$ in the right peak of the bimodal distribution may be the result of transportation from polluted regions.

\subsection{Diurnal variation in $D_{\mathrm{p}} / D_{\mathrm{c}}$}

The temporal variation in $D_{\mathrm{p}} / D_{\mathrm{c}}$ exhibited a clear day-high and night-low pattern. Figure 8 exhibits the diurnal trend of $D_{\mathrm{p}} / D_{\mathrm{c}}$. The mean $D_{\mathrm{p}} / D_{\mathrm{c}}$ increased during the daytime, with a peak (1.20) at 14:00 LST and a minimum (1.12) at 06:00 LST. Coating thickness $\left(D_{\mathrm{p}} / D_{\mathrm{c}}\right)$ was controlled by the competing effects of emissions and aging because freshly emitted thinly coated $\mathrm{rBC}$ tends to decrease $D_{\mathrm{p}} / D_{\mathrm{c}}$ and the aging process tends to increase $D_{\mathrm{p}} / D_{\mathrm{c}}$. The increasing trend of $D_{\mathrm{p}} / D_{\mathrm{c}}$ during the day could be explained by the prevailing aging process, whereas the decreasing trend at night can be explained by the prevailing emissions process, as the photochemical condensation aging during the day was much faster than the coagulation aging at night (Riemer et al., 2004; Chen et al., 2017). The advection of aged rBCcontaining particles from the upper boundary layer with the development of boundary layer during daytime may be another reason for the increase in $D_{\mathrm{p}} / D_{\mathrm{c}}$. By measuring the $D_{\mathrm{p}}$ from 06:00 to 14:00 LST, the $D_{\mathrm{p}}$ growth rate was calculated to be $2.3 \mathrm{~nm} \mathrm{~h}^{-1}$. A larger $D_{\mathrm{p}}$ growth rate was found in the period with a high $\mathrm{O}_{x}$ concentration, which may be favorable for the formation of coating material on $\mathrm{rBC}$. The photochemical process and condensation aging have proven to be very efficient during the day. Using a smog chamber, Peng et al. (2016) found that the $D_{\mathrm{p}}$ growth rate of rBCcontaining particles could reach $26 \mathrm{~nm} \mathrm{~h}^{-1}$ in Beijing's urban area. Although the photochemical process and condensation may rapidly increase the $D_{\mathrm{p}}$, the difference between the present study and the smog chamber results indicated that the "apparent" $D_{\mathrm{p}}$ growth rate in the ambient measurement was relatively low given the continuous freshly emitted $\mathrm{rBC}$ in urban Beijing. Thus, the $D_{\mathrm{p}} / D_{\mathrm{c}}$ was always at a low level, resulting in little light absorption enhancement during the summer.

\section{Discussion}

\subsection{Morphological evolution of rBC-containing particles}

\subsubsection{Morphology of bare rBC}

By coupling DMA and SP2, the mass and the mobility diameter of bare $\mathrm{rBC}\left(D_{\mathrm{p}} / D_{\mathrm{c}} \approx 1.0\right)$ can be obtained simultaneously, and, therefore, the effective density ( $\left.\rho_{\text {eff }}\right)$ can be calculated. The $\rho_{\text {eff }}$ of the ambient bare $\mathrm{rBC}$ was measured on a clean day ( 8 June) and a polluted day (13 June). The $\rho_{\text {eff }}$ of bare $\mathrm{rBC}$ at $200-300 \mathrm{~nm}$ ranged from 0.41 to $0.29 \mathrm{~g} \mathrm{~cm}^{-3}$, which was much smaller than the material density of $\mathrm{rBC}$ $\left(1.8 \mathrm{~g} \mathrm{~cm}^{-3}\right)$. This significant discrepancy indicates that bare $\mathrm{rBC}$ was in a fractal structure consistent with the previous research from electron microscopic images, which showed that bare $\mathrm{rBC}$ was in a fractal chain-like structure (Adachi and Buseck, 2013; Li et al., 2003; Wang et al., 2017). The 


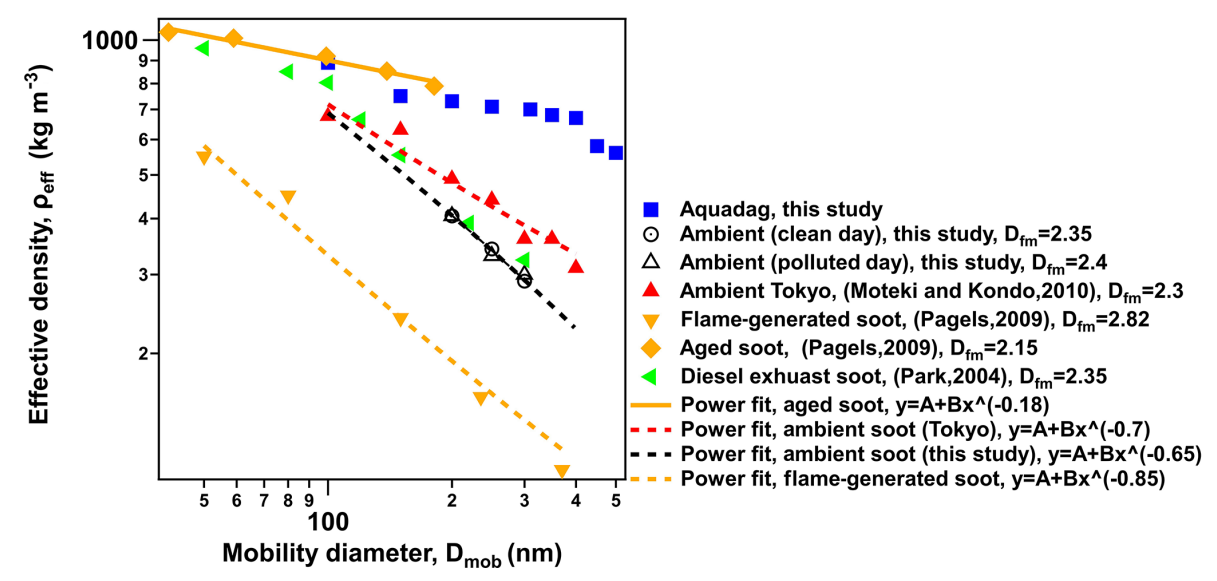

Figure 9. Relationship between effective density and mobility diameter of rBC-containing particles. The black circle and triangle denote the fresh $\mathrm{rBC}$-containing particles $\left(D_{\mathrm{p}} / D_{\mathrm{c}}=1\right)$ measured on clean days and polluted days in this study. Other markers denote the data from previous research.

effective densities showed no evident difference between the polluted day and the clean day because the bare rBC particles were freshly emitted and only affected by local sources. A power law is always used to describe the fractal-like aggregates of particles: $M_{\mathrm{p}} \propto D_{\mathrm{mob}}^{D_{\mathrm{fm}}}$ (Moteki and Kondo, 2010; Park et al., 2004), where $D_{\mathrm{fm}}$ is defined as the mass fractal dimension that is an indicator of particle compactness. The value of $D_{\mathrm{fm}}$ is 3 for ideal spherical particles and less than 3 for fractal particles. Based on the equation for $\rho_{\text {eff }}$, the following relationship can be found: $\rho_{\mathrm{eff}} \propto D_{\mathrm{mob}}^{D_{\mathrm{fm}-3}}$. Thus, a larger bare rBC had a smaller $\rho_{\text {eff }}$, which was consistent with the results in Fig. 9. A power function was used to fit the observed data. $\rho_{\text {eff }} \propto D_{\text {mob }}^{-0.65}$ and $\rho_{\text {eff }} \propto D_{\text {mob }}^{-0.6}$ were found separately on clean and polluted days, corresponding to the mass fractal dimensions of 2.35 and 2.40 , respectively. These mass fractal dimensions from the summer in Beijing are similar to the observations $\left(D_{\mathrm{fm}}=2.30\right)$ from urban Tokyo (Moteki and Kondo, 2010) and the diesel exhaust measurement $\left(D_{\mathrm{fm}}=2.35\right)$ (Park et al., 2004), suggesting that the freshly emitted bare $\mathrm{rBC}$ particles originated primarily from traffic sources. Traffic may contribute a majority of the fresh $\mathrm{rBC}$ during both polluted and clean periods in the summer.

\subsubsection{Morphology of rBC-containing particles with increasing coating thickness}

The morphological characteristics of rBC-containing particles were investigated by comparing the $\sigma_{\text {measured }}$ and $\sigma_{\text {model }}$ using a CPMA-SP2 system first proposed by Liu et al. (2017). The comparison of $\sigma_{\text {measured }}$ and $\sigma_{\text {model }}$ as a function of $M_{\mathrm{R}}$ for a particle mass of $10 \mathrm{fg}$ is illustrated in Fig. 10a. If the ratio of $\sigma_{\text {measured }}$ and $\sigma_{\text {model }}$ equals 1 , it implies that the scattering cross section measured by SP2 is the same as the model prediction under the assumption of a core-shell mixing structure; thus, the rBC-containing particle was likely a core-shell structure. When the rBC was bare
$\left(M_{\mathrm{R}} \approx 0\right)$, the $\mathrm{rBC}$ was in a fractal structure, as discussed in Sect. 4.1.1. With increasing $M_{\mathrm{R}}$, the $\sigma_{\text {measured }} / \sigma_{\text {model }}$ gradually decreased until $M_{\mathrm{R}}=1.5$, indicating that the coating material may not be sufficient to encapsulate $\mathrm{rBC}$ and that the $\mathrm{rBC}$-containing particles tended not to be away from a core-shell structure. Liu et al. (2017) showed that rBCcontaining particles with $M_{\mathrm{R}}<1.5$ primarily presented an external structure. When $1.5<M_{\mathrm{R}}<6$, the $\sigma_{\text {measured }} / \sigma_{\text {model }}$ steadily increased, which implied that the shape of rBCcontaining particles gradually transformed to become more compact, with a core-shell-like structure, in this stage. When $M_{\mathrm{R}}>6$, the $\sigma_{\text {measured }} / \sigma_{\text {model }}$ approached 1 , indicating that the rBC-containing particles were in a core-shell-like structure in this stage. Similar phenomena were found in the relationship of $\sigma_{\text {measured }} / \sigma_{\text {model }}$ and $M_{\mathrm{R}}$ for particle masses of $5 \mathrm{fg}$, as illustrated in Fig. 10b. However, when $M_{\mathrm{R}} \approx 0.1, \sigma_{\text {measured }}$ was consistent with the model prediction for a particle mass of $5 \mathrm{fg}$. This is because the scattering signal was not sensitive to the irregularity of smaller-sized particles (Moteki et al., 2010). Therefore, a Mie theory-based core-shell model could capture the main morphological features.

Different techniques have been used to explore the morphology of rBC-containing particles in ambient and laboratory measurements (Zhang et al., 2008; Peng et al., 2016; Pagels et al., 2009). It is generally agreed that the morphology of rBC-containing particles will become more compact with the aging process or with increasing coating thickness. However, this study reveals that the morphology transform may only be true when the coating is thick enough $\left(M_{\mathrm{R}}>1.5\right)$, and the coatings may only attach to $\mathrm{rBC}$ and slightly influence rBC-containing particles' morphology when the coating is not thick enough $\left(M_{\mathrm{R}}<1.5\right)$.

Based on the relationship between the $\sigma_{\text {measured }} / \sigma_{\text {model }}$ and $M_{\mathrm{R}}$, the $\mathrm{rBC}$-containing particles are classified into three groups: external stage $\left(0<M_{\mathrm{R}}<1.5\right)$, transit stage $\left(1.5<M_{\mathrm{R}}<6\right)$ and core-shell stage $\left(M_{\mathrm{R}}>6\right)$. A similar vari- 

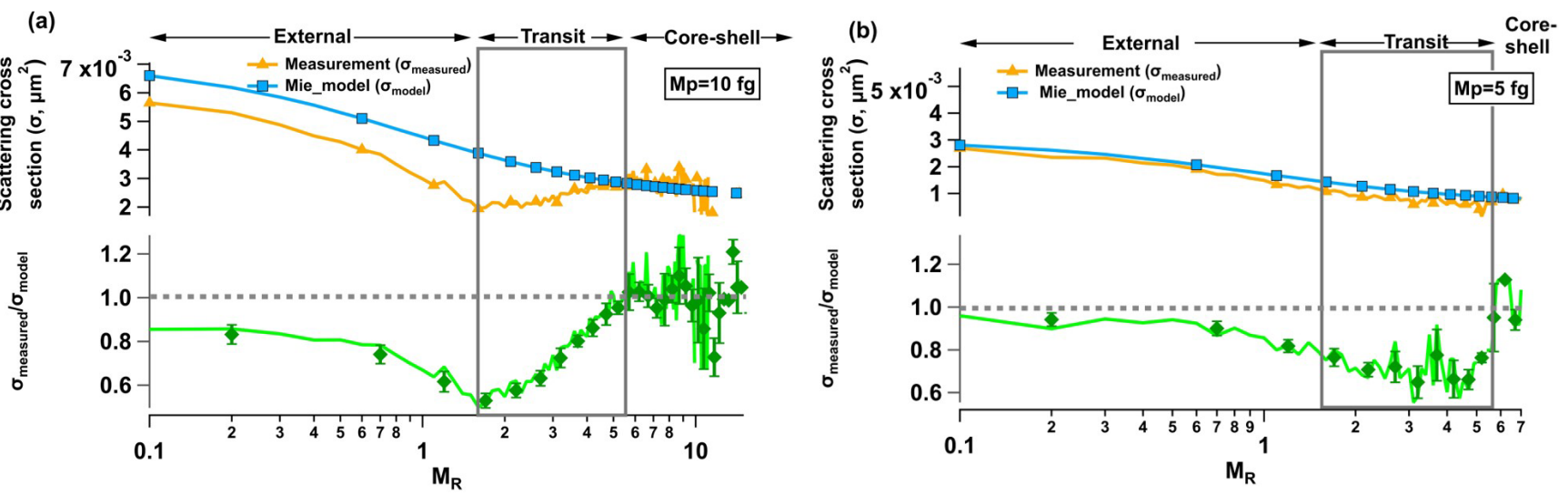

Figure 10. (a) Scattering cross section of rBC-containing particles as measured by SP2 (yellow line) and calculated by Mie theory (blue line), assuming a core-shell structure. Bottom panel: the ratio (green line) between these two scattering cross sections at a CPMA set point of $10 \mathrm{fg}$ as a function of $M_{\mathrm{R}}$ (the mass ratio of nonrefractory matter to $\mathrm{rBC}$ ). (b) The same as (a) but for a CPMA set point of 5 fg.

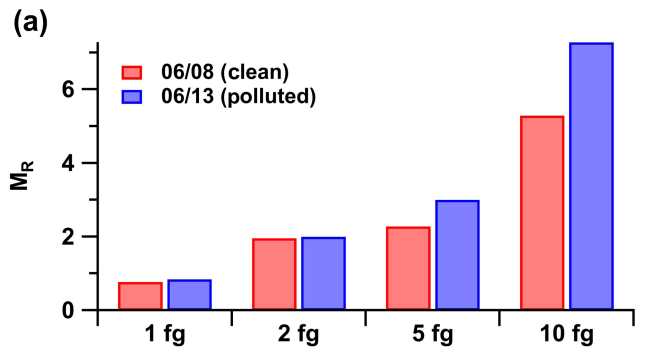

(b)

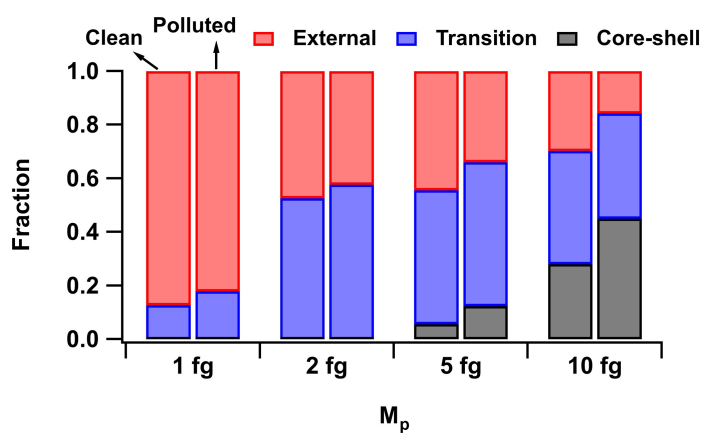

Figure 11. (a) The average $M_{\mathrm{R}}$ (the mass ratio of nonrefractory matter to $\mathrm{rBC}$ ) under different CPMA set points $(1,2,5,10 \mathrm{fg})$. (b) The fraction of different types of rBC-containing particles under different CPMA set points under varied pollution conditions.

ation between the $\sigma_{\text {measured }} / \sigma_{\text {model }}$ and $M_{\mathrm{R}}$ was also found by Liu et al. (2017) and Wu et al. (2018). The $M_{\mathrm{R}}$ transition point from the transit stage and core-shell stage determined by Liu et al. (2017) is slightly lower than that in this study. Liu et al. (2017) found that the $M_{\mathrm{R}}$ transition point varied among different $\mathrm{rBC}$ sources. In addition to $\mathrm{rBC}$ sources, the environmental conditions during the aging process of $\mathrm{rBC}$ containing particles, such as temperature and humidity, may also influence the $\mathrm{rBC}$-containing particle morphology. We determined the $M_{\mathrm{R}}$ transition point in Beijing in summer.
More work needs to be done in the future to better quantify $M_{\mathrm{R}}$ in different situations.

The combined CPMA and SP2 measurements were conducted separately on a clean day (8 June) and a polluted day (13 June). Figure 11a presents the average $M_{\mathrm{R}}$ for different CPMA set points $(1,2,5$ and $10 \mathrm{fg})$ on 8 and 13 June. The average $M_{\mathrm{R}}$ is 0.77 for $M_{\mathrm{p}}=1 \mathrm{fg}$ and 5.29 for $M_{\mathrm{p}}=10 \mathrm{fg}$ on the clean day, whereas the average $M_{\mathrm{R}}$ is 0.84 for $M_{\mathrm{p}}=1 \mathrm{fg}$ and 7.28 for $M_{\mathrm{p}}=10 \mathrm{fg}$ on the polluted day. The average $M_{\mathrm{R}}$ values of the polluted day were all larger than those on the clean day for the four $M_{\mathrm{p}}$ points. This result demonstrated that $\mathrm{rBC}$ had more coating material on the polluted day than on the clean day. Based on the $M_{\mathrm{R}}$ transition points discussed above, the rBC-containing particles were classified into three stages, as shown in Fig. 11b. The rBC-containing particles with $M_{\mathrm{p}}=1 \mathrm{fg}$ were primarily in the external mixing stage regardless of the pollution conditions. With an increase in $M_{\mathrm{p}}$, more $\mathrm{rBC}$-containing particles were in the transition or core-shell stage. On the clean day, $28 \%$ of the $\mathrm{rBC}$-containing particles were in the core-shell stage, when $M_{\mathrm{p}}=10 \mathrm{fg}$. However, on the polluted day, $45 \%$ of the $\mathrm{rBC}$-containing particles were in the core-shell stage, when $M_{\mathrm{p}}=10 \mathrm{fg}$. This phenomenon implied that most $\mathrm{rBC}$ containing particles are not in an ideal core-shell structure on clean days, whereas more rBC-containing particles were in a core-shell structure with thicker coatings on the polluted day.

\subsection{Implications of $\mathrm{rBC}$-containing particle morphology for light absorption}

The morphology of rBC-containing particles varied with $M_{\mathrm{R}}$. A simple core-shell model, as always used in the previous research to determine optical properties, will certainly cause bias. Based on the classification of the rBC-containing particles according to the relationship between $\sigma_{\text {measured }} / \sigma_{\text {model }}$ and $M_{\mathrm{R}}$, Liu et al. (2017) proposed a simple morphology- 

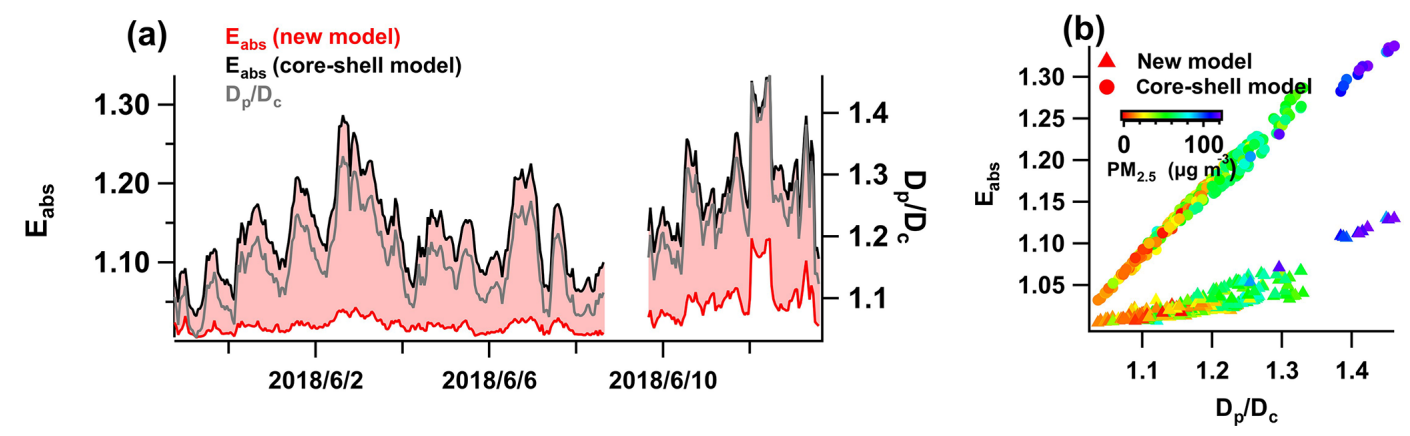

Figure 12. (a) Time series of $D_{\mathrm{p}} / D_{\mathrm{c}}$ with $D_{\mathrm{c}}=180 \pm 10 \mathrm{~nm}$ and $E_{\mathrm{abs}}$ at $550 \mathrm{~nm}$ wavelength using the core-shell model and the morphologydependent model. (b) Relationship between $E_{\mathrm{abs}}$ and $D_{\mathrm{p}} / D_{\mathrm{c}}$. Circles denote the $E_{\mathrm{abs}}$ derived from the core-shell model, and triangles denote the $E_{\text {abs }}$ derived from the morphology-dependent model.

dependent scheme in which the rBC-containing particles at the external stage were considered to have no absorption enhancement $\left(E_{\mathrm{abs}}\right)$ and the $\mathrm{rBC}$-containing particles at the core-shell stage were considered to have the same $E_{\text {abs }}$ from the Mie theory under the assumption of a perfect core-shell structure. The $E_{\text {abs }}$ at the transit stage was calculated by the interpolation of $E_{\text {abs }}$ between the external and core-shell stages. A graphical and detailed description of the calculation of $E_{\mathrm{abs}}$ can be found in Fig. S6. Liu et al. (2017) proved that this morphology-dependent scheme is in good agreement with the measured $E_{\text {abs. }}$. Thus, the $E_{\text {abs }}$ at the $550 \mathrm{~nm}$ wavelength with $D_{\mathrm{c}}=180 \pm 10 \mathrm{~nm}$ was calculated separately using the core-shell model and the morphology-dependent scheme to quantify the uncertainty of using a core-shell model, as shown in Fig. 12. The absorption enhancement was 1.15 , on average, using the core-shell model but was only 1.03 using the new scheme. The $E_{\text {abs }}$ determined by the core-shell model was overestimated by $12 \%$ because the observed averaged coating thickness $\left(D_{\mathrm{p}} / D_{\mathrm{c}}=1.2\right)$ determined from single-SP2 measurements corresponded to $M_{\mathrm{R}}=0.37$, suggesting that the coating material was not sufficient and most of the rBC-containing particles were not in a core-shell structure in summer in Beijing. Thus, it is necessary to consider the morphology of rBC-containing particles when calculating their optical properties.

\section{Conclusions}

The mixing characteristics of $\mathrm{rBC}$-containing particles were investigated in Beijing during the early summer of 2018 using a single-particle soot photometer (SP2). The rBC had an approximately lognormal distribution as a function of the mass equivalent diameter $\left(D_{\mathrm{c}}\right)$, characterized by a mass median diameter (MMD) of $171 \mathrm{~nm}$, which is consistent with previous urban measurements. The mass size distribution was highly associated with the meteorological conditions. Heavy rain events caused the $\mathrm{rBC}$ mass size distribution to be smaller, indicating that wet scavenging may be a more ef- ficient removal mechanism for larger $\mathrm{rBC}$-containing particles. The mass size distribution of rBC shifted to larger sizes when southerly winds prevailed, which was primarily caused by the different $\mathrm{rBC}$ sources in the south.

The $D_{\mathrm{p}} / D_{\mathrm{c}}$ was 1.20 on average, with $D_{\mathrm{c}}=180 \mathrm{~nm}$ during the investigation period, indicating a low coating thickness of rBC during the summer. The coating thickness exhibited a clear diurnal pattern with a peak at 14:00 LST, increasing from 06:00 to 14:00 LST at a $D_{\mathrm{p}}$ growth rate of $2.3 \mathrm{~nm} \mathrm{~h}^{-1}$, with $D_{\mathrm{c}}=180 \mathrm{~nm}$ during the day. The growth rate was much higher in high- $\mathrm{O}_{x}$ periods. However, this growth rate was significantly lower than that in the smog chamber results, with a growth rate of $26 \mathrm{~nm} \mathrm{~h}^{-1}$ because the continuously emitted fresh $\mathrm{rBC}$ lowered the $D_{\mathrm{p}} / D_{\mathrm{c}}$ in ambient measurements. Although photochemical aging may be very efficient, with continuously emitted fresh $\mathrm{rBC}$, the $D_{\mathrm{p}} / D_{\mathrm{c}}$ increase in the ambient air was very slow, indicating that the $\mathrm{rBC}$-containing particles were primarily at a low $D_{\mathrm{p}} / D_{\mathrm{c}}$ level in summer.

A tandem measurement system with a differential mobility analyzer (DMA) and a centrifugal particle mass analyzer (CPMA) were coupled with an SP2 to investigate the detailed characteristics of $\mathrm{rBC}$-containing particles in summer. The results showed that the effective density of bare $\operatorname{rBC}\left(D_{\mathrm{p}} / D_{\mathrm{c}}=1.0\right)$ was determined to be $0.41-0.30 \mathrm{~g} \mathrm{~cm}^{-3}$ for $D_{\mathrm{c}}=200-300 \mathrm{~nm}$. These effective densities were significantly lower than the rBC material density $\left(1.8 \mathrm{~g} \mathrm{~cm}^{-3}\right)$, suggesting that the bare $\mathrm{rBC}$ was in a fractal structure. The corresponding mass fractal dimension $\left(D_{\mathrm{fm}}\right)$ was 2.35 , which agrees well with the $D_{\mathrm{fm}}$ of the direct measurement from vehicles, and was unchanged regardless of pollution, indicating that traffic emissions are a major source of fresh bare $\mathrm{rBC}$ on both clean and polluted days during the summer in Beijing. With increasing coating thickness, the morphology of rBC changed from a fractal structure to a compact core-shell structure. When $M_{\mathrm{R}}\left(M_{\text {coat }} / M_{\mathrm{rBC}}\right)<1.5$, rBCcontaining particles were in an external structure. When $M_{\mathrm{R}}>6$, rBC-containing particles were in a core-shell struc- 
ture. When $1.5<M_{\mathrm{R}}<6$, the rBC-containing particles were in a transition stage.

Based on the core-shell model and Mie theory, a new morphology-dependent absorption enhancement $\left(E_{\mathrm{abs}}\right)$ scheme was proposed and applied to the ambient measurements. A simulation showed that the $E_{\text {abs }}$ averaged to 1.03 with $D_{\mathrm{c}}=180 \mathrm{~nm}$ at a wavelength of $550 \mathrm{~nm}$ in the summer. The core-shell model overestimated the $E_{\text {abs }}$ by $12 \%$.

Data availability. To request the data given in this study, please contact Xiaole Pan at the Institute of Atmospheric Physics, Chinese Academy of Sciences, via email (panxiaole@mail.iap.ac.cn).

Supplement. The supplement related to this article is available online at: https://doi.org/10.5194/acp-20-5771-2020-supplement.

Author contributions. HL and XP designed the research. HL, XP, XL, YT, YS, PF and ZW performed the experiments. HL, XP, DL and $\mathrm{XC}$ performed the data analysis. HL and XP wrote the paper.

Competing interests. The authors declare that they have no conflict of interest.

Financial support. This research has been supported by the National Natural Science Foundation of China (grant nos. 41877314, 41675128).

Review statement. This paper was edited by Thomas Karl and reviewed by three anonymous referees.

\section{References}

Adachi, K. and Buseck, P. R.: Changes of ns-soot mixing states and shapes in an urban area during CalNex, J. Geophys. Res.-Atmos., 118, 3723-3730, https://doi.org/10.1002/jgrd.50321, 2013.

Adler, G., Riziq, A. A., Erlick, C., and Rudich, Y.: Effect of intrinsic organic carbon on the optical properties of fresh diesel soot, P. Natl. Acad. Sci. USA, 107, 6699-6704, https://doi.org/10.1073/pnas.0903311106, 2010.

Apte, J. S., Marshall, J. D., Cohen, A. J., and Brauer, M.: Addressing Global Mortality from Ambient $\mathrm{PM}_{2.5}$, Environ. Sci. Technol., 49, 8057-8066, https://doi.org/10.1021/acs.est.5b01236, 2015.

Bond, T. C., Doherty, S. J., Fahey, D., Forster, P., Berntsen, T., DeAngelo, B., Flanner, M., Ghan, S., Kärcher, B., and Koch, D.: Bounding the role of black carbon in the climate system: A scientific assessment, J. Geophys. Res.-Atmos., 118, 5380-5552, 2013.

Cao, J. J., Lee, S. C., Ho, K. F., Zou, S. C., Fung, K., Li, Y., Watson, J. G., and Chow, J. C.: Spatial and seasonal variations of atmospheric organic carbon and elemental carbon in Pearl River Delta Region, China, Atmos. Environ., 38, 4447-4456, https://doi.org/10.1016/j.atmosenv.2004.05.016, 2004.

Cao, J. J., Lee, S. C., Chow, J. C., Watson, J. G., Ho, K. F., Zhang, R. J., Jin, Z. D., Shen, Z. X., Chen, G. C., Kang, Y. M., Zou, S. C., Zhang, L. Z., Qi, S. H., Dai, M. H., Cheng, Y., and $\mathrm{Hu}, \mathrm{K}$.: Spatial and seasonal distributions of carbonaceous aerosols over China, J. Geophys. Res.-Atmos., 112, D22s11, https://doi.org/10.1029/2006jd008205, 2007.

Cappa, C. D., Onasch, T. B., Massoli, P., Worsnop, D. R., Bates, T. S., Cross, E. S., Davidovits, P., Hakala, J., Hayden, K. L., Jobson, B. T., Kolesar, K. R., Lack, D. A., Lerner, B. M., Li, S. M., Mellon, D., Nuaaman, I., Olfert, J. S., Petaja, T., Quinn, P. K., Song, C., Subramanian, R., Williams, E. J., and Zaveri, R. A.: Radiative Absorption Enhancements Due to the Mixing State of Atmospheric Black Carbon, Science, 337, 1078-1081, https://doi.org/10.1126/science.1223447, 2012.

Chen, X. S., Wang, Z. F., Yu, F. Q., Pan, X. L., Li, J., Ge, B. Z., Wang, Z., Hu, M., Yang, W. Y., and Chen, H. S.: Estimation of atmospheric aging time of black carbon particles in the polluted atmosphere over centraleastern China using microphysical process analysis in regional chemical transport model, Atmos. Environ., 163, 44-56, https://doi.org/10.1016/j.atmosenv.2017.05.016, 2017.

Cheng, Y. F., Su, H., Rose, D., Gunthe, S. S., Berghof, M., Wehner, B., Achtert, P., Nowak, A., Takegawa, N., Kondo, Y., Shiraiwa, M., Gong, Y. G., Shao, M., Hu, M., Zhu, T., Zhang, Y. H., Carmichael, G. R., Wiedensohler, A., Andreae, M. O., and Poschl, U.: Size-resolved measurement of the mixing state of soot in the megacity Beijing, China: diurnal cycle, aging and parameterization, Atmos. Chem. Phys., 12, 4477-4491, https://doi.org/10.5194/acp-12-4477-2012, 2012.

Ding, A. J., Huang, X., Nie, W., Sun, J. N., Kerminen, V. M., Petaja, T., Su, H., Cheng, Y. F., Yang, X. Q., Wang, M. H., Chi, X. G., Wang, J. P., Virkkula, A., Guo, W. D., Yuan, J., Wang, S. Y., Zhang, R. J., Wu, Y. F., Song, Y., Zhu, T., Zilitinkevich, S., Kulmala, M., and Fu, C. B.: Enhanced haze pollution by black carbon in megacities in China, Geophys. Res. Lett., 43, 2873-2879, https://doi.org/10.1002/2016g1067745, 2016.

Gao, R. S., Schwarz, J. P., Kelly, K. K., Fahey, D. W., Watts, L. A., Thompson, T. L., Spackman, J. R., Slowik, J. G., Cross, E. S., Han, J. H., Davidovits, P., Onasch, T. B., and Worsnop, D. R.: A novel method for estimating lightscattering properties of soot aerosols using a modified singleparticle soot photometer, Aerosol Sci. Technol., 41, 125-135, https://doi.org/10.1080/02786820601118398, 2007.

Gong, X. D., Zhang, C., Chen, H., Nizkorodov, S. A., Chen, J. M., and Yang, X.: Size distribution and mixing state of black carbon particles during a heavy air pollution episode in Shanghai, Atmos. Chem. Phys., 16, 5399-5411, https://doi.org/10.5194/acp16-5399-2016, 2016.

Gysel, M., Laborde, M., Olfert, J. S., Subramanian, R., and Grohn, A. J.: Effective density of Aquadag and fullerene soot black carbon reference materials used for SP2 calibration, Atmos. Meas. Tech., 4, 2851-2858, https://doi.org/10.5194/amt-4-2851-2011, 2011.

Huang, X. F., Sun, T. L., Zeng, L. W., Yu, G. H., and Luan, S. J.: Black carbon aerosol characterization in a coastal city in South China using a single particle soot photometer, Atmos. Envi- 
ron., 51, 21-28, https://doi.org/10.1016/j.atmosenv.2012.01.056, 2012.

Jacobson, M. Z.: Strong radiative heating due to the mixing state of black carbon in atmospheric aerosols, Nature, 409, 695-697, https://doi.org/10.1038/35055518, 2001.

Laborde, M., Mertes, P., Zieger, P., Dommen, J., Baltensperger, U., and Gysel, M.: Sensitivity of the Single Particle Soot Photometer to different black carbon types, Atmos. Meas. Tech., 5, 10311043, https://doi.org/10.5194/amt-5-1031-2012, 2012.

Laborde, M., Crippa, M., Tritscher, T., Juranyi, Z., Decarlo, P. F., Temime-Roussel, B., Marchand, N., Eckhardt, S., Stohl, A., Baltensperger, U., Prevot, A. S. H., Weingartner, E., and Gysel, M.: Black carbon physical properties and mixing state in the European megacity Paris, Atmos. Chem. Phys., 13, 5831-5856, https://doi.org/10.5194/acp-13-5831-2013, 2013.

Lack, D. A., Langridge, J. M., Bahreini, R., Cappa, C. D., Middlebrook, A. M., and Schwarz, J. P.: Brown carbon and internal mixing in biomass burning particles, P. Natl. Acad. Sci. USA, 109, 14802-14807, https://doi.org/10.1073/pnas.1206575109, 2012.

Lan, Z. J., Huang, X. F., Yu, K. Y., Sun, T. L., Zeng, L. W., and $\mathrm{Hu}, \mathrm{M}$. : Light absorption of black carbon aerosol and its enhancement by mixing state in an urban atmosphere in South China, Atmos. Environ., 69, 118-123, https://doi.org/10.1016/j.atmosenv.2012.12.009, 2013.

Li, J., Posfai, M., Hobbs, P. V., and Buseck, P. R.: Individual aerosol particles from biomass burning in southern Africa: 2. Compositions and aging of inorganic particles, J. Geophys. Res.-Atmos., 108, 12, https://doi.org/10.1029/2002jd002310, 2003.

Liu, D., Allan, J., Whitehead, J., Young, D., Flynn, M., Coe, H., McFiggans, G., Fleming, Z. L., and Bandy, B.: Ambient black carbon particle hygroscopic properties controlled by mixing state and composition, Atmos. Chem. Phys., 13, 2015-2029, https://doi.org/10.5194/acp-13-2015-2013, 2013.

Liu, D., Allan, J. D., Young, D. E., Coe, H., Beddows, D., Fleming, Z. L., Flynn, M. J., Gallagher, M. W., Harrison, R. M., Lee, J., Prevot, A. S. H., Taylor, J. W., Yin, J., Williams, P. I., and Zotter, P.: Size distribution, mixing state and source apportionment of black carbon aerosol in London during wintertime, Atmos. Chem. Phys., 14, 10061-10084, https://doi.org/10.5194/acp-1410061-2014, 2014.

Liu, D. T., Taylor, J. W., Young, D. E., Flynn, M. J., Coe, H., and Allan, J. D.: The effect of complex black carbon microphysics on the determination of the optical properties of brown carbon, Geophys. Res. Lett., 42, 613-619, https://doi.org/10.1002/2014g1062443, 2015.

Liu, D. T., Whitehead, J., Alfarra, M. R., Reyes-Villegas, E., Spracklen, D. V., Reddington, C. L., Kong, S. F., Williams, P. I., Ting, Y. C., Haslett, S., Taylor, J. W., Flynn, M. J., Morgan, W. T., McFiggans, G., Coe, H., and Allan, J. D.: Black-carbon absorption enhancement in the atmosphere determined by particle mixing state, Nat. Geosci., 10, 184-U132, https://doi.org/10.1038/Ngeo2901, 2017.

Menon, S., Hansen, J., Nazarenko, L., and Luo, Y.: Climate effects of black carbon aerosols in China and India, Science, 297, 22502253, 2002.

Moteki, N. and Kondo, Y.: Dependence of Laser-Induced Incandescence on Physical Properties of Black Carbon Aerosols: Measurements and Theoretical Interpretation, Aerosol Sci. Technol.,
44, 663-675, https://doi.org/10.1080/02786826.2010.484450, 2010.

Moteki, N., Kondo, Y., and Nakamura, S.: Method to measure refractive indices of small nonspherical particles: Application to black carbon particles, J. Aerosol. Sci., 41, 513-521, https://doi.org/10.1016/j.jaerosci.2010.02.013, 2010.

Pagels, J., Khalizov, A. F., McMurry, P. H., and Zhang, R. Y.: Processing of Soot by Controlled Sulphuric Acid and Water CondensationMass and Mobility Relationship, Aerosol Sci. Technol., 43, 629-640, https://doi.org/10.1080/02786820902810685, 2009.

Pan, X. L., Kanaya, Y., Taketani, F., Miyakawa, T., Inomata, S., Komazaki, Y., Tanimoto, H., Wang, Z., Uno, I., and Wang, Z. F.: Emission characteristics of refractory black carbon aerosols from fresh biomass burning: a perspective from laboratory experiments, Atmos. Chem. Phys., 17, 13001-13016, https://doi.org/10.5194/acp-17-13001-2017, 2017.

Park, K., Kittelson, D. B., and McMurry, P. H.: Structural properties of diesel exhaust particles measured by transmission electron microscopy (TEM): Relationships to particle mass and mobility, Aerosol Sci. Technol., 38, 881-889, https://doi.org/10.1080/027868290505189, 2004.

Peng, J. F., Hu, M., Guo, S., Du, Z. F., Zheng, J., Shang, D. J., Zamora, M. L., Zeng, L. M., Shao, M., Wu, Y. S., Zheng, J., Wang, Y., Glen, C. R., Collins, D. R., Molina, M. J., and Zhang, R. Y.: Markedly enhanced absorption and direct radiative forcing of black carbon under polluted urban environments, P. Natl. Acad. Sci. USA, 113, 4266-4271, https://doi.org/10.1073/pnas.1602310113, 2016.

Popovicheva, O. B., Persiantseva, N. M., Kireeva, E. D., Khokhlova, T. D., and Shonija, N. K.: Quantification of the Hygroscopic Effect of Soot Aging in the Atmosphere: Laboratory Simulations, J. Phys. Chem. A, 115, 298-306, https://doi.org/10.1021/jp109238x, 2011.

Qin, Y. and Xie, S. D.: Spatial and temporal variation of anthropogenic black carbon emissions in China for the period 1980-2009, Atmos. Chem. Phys., 12, 4825-4841, https://doi.org/10.5194/acp-12-4825-2012, 2012.

Ramanathan, V. and Carmichael, G.: Global and regional climate changes due to black carbon, Nat. Geosci., 36, 335-358, 2008.

Ramanathan, V., Crutzen, P. J., Kiehl, J. T., and Rosenfeld, D.: Atmosphere - Aerosols, climate, and the hydrological cycle, Science, 294, 2119-2124, https://doi.org/10.1126/science.1064034, 2001.

Riemer, N., Vogel, H., and Vogel, B.: Soot aging time scales in polluted regions during day and night, Atmos. Chem. Phys., 4, 1885-1893, https://doi.org/10.5194/acp-4-1885-2004, 2004.

Schnaiter, M., Linke, C., Möhler, O., Naumann, K. H., Saathoff, H., Wagner, R., Schurath, U., and Wehner, B.: Absorption amplification of black carbon internally mixed with secondary organic aerosol, J. Geophys. Res.-Atmos., 110, 11, https://doi.org/10.1029/2005jd006046, 2005.

Schwarz, J. P., Gao, R. S., Spackman, J. R., Watts, L. A., Thomson, D. S., Fahey, D. W., Ryerson, T. B., Peischl, J., Holloway, J. S., Trainer, M., Frost, G. J., Baynard, T., Lack, D. A., de Gouw, J. A., Warneke, C., and Del Negro, L. A.: Measurement of the mixing state, mass, and optical size of individual black carbon particles in urban and biomass burning emissions, Geophys. Res. Lett., 35, L13810, https://doi.org/10.1029/2008gl033968, 2008. 
Shiraiwa, M., Kondo, Y., Moteki, N., Takegawa, N., Sahu, L., Takami, A., Hatakeyama, S., Yonemura, S., and Blake, D.: Radiative impact of mixing state of black carbon aerosol in Asian outflow, J. Geophys. Res.-Atmos., 113, 13, https://doi.org/10.1029/2008jd010546, 2008.

Shiraiwa, M., Kondo, Y., Iwamoto, T., and Kita, K.: Amplification of Light Absorption of Black Carbon by Organic Coating, Aerosol Sci. Technol., 44, 46-54, https://doi.org/10.1080/02786820903357686, 2010.

Taylor, J. W., Allan, J. D., Allen, G., Coe, H., Williams, P. I., Flynn, M. J., Le Breton, M., Muller, J. B. A., Percival, C. J., Oram, D., Forster, G., Lee, J. D., Rickard, A. R., Parrington, M., and Palmer, P. I.: Size-dependent wet removal of black carbon in Canadian biomass burning plumes, Atmos. Chem. Phys., 14, 13755-13771, https://doi.org/10.5194/acp-14-137552014, 2014.

Taylor, J. W., Allan, J. D., Liu, D., Flynn, M., Weber, R., Zhang, X., Lefer, B. L., Grossberg, N., Flynn, J., and Coe, H.: Assessment of the sensitivity of core/shell parameters derived using the singleparticle soot photometer to density and refractive index, Atmos. Meas. Tech., 8, 1701-1718, https://doi.org/10.5194/amt-8-1701$2015,2015$.

Wang, Q. Y., Huang, R. J., Zhao, Z. Z., Cao, J. J., Ni, H. Y., Tie, X. X., Zhao, S. Y., Su, X. L., Han, Y. M., Shen, Z. X., Wang, Y. C., Zhang, N. N., Zhou, Y. Q., and Corbin, J. C.: Physicochemical characteristics of black carbon aerosol and its radiative impact in a polluted urban area of China, J. Geophys. Res.-Atmos., 121, 12505-12519, https://doi.org/10.1002/2016jd024748, 2016.

Wang, Q. Y., Cao, J. J., Han, Y. M., Tian, J., Zhu, C. S., Zhang, Y. G., Zhang, N. N., Shen, Z. X., Ni, H. Y., Zhao, S. Y., and Wu, J. R.: Sources and physicochemical characteristics of black carbon aerosol from the southeastern Tibetan Plateau: internal mixing enhances light absorption, Atmos. Chem. Phys., 18, 4639-4656, https://doi.org/10.5194/acp-18-4639-2018, 2018.
Wang, Y. Y., Liu, F. S., He, C. L., Bi, L., Cheng, T. H., Wang, Z. L., Zhang, H., Zhang, X. Y., Shi, Z. B., and Li, W. J.: Fractal Dimensions and Mixing Structures of Soot Particles during Atmospheric Processing, Environ. Sci. Tech. Let., 4, 487-493, https://doi.org/10.1021/acs.estlett.7b00418, 2017.

Wu, Y., Cheng, T. H., Liu, D. T., Allan, J. D., Zheng, L. J., and Chen, H.: Light Absorption Enhancement of Black Carbon Aerosol Constrained by Particle Morphology, Environ. Sci. Technol., 52, 6912-6919, https://doi.org/10.1021/acs.est.8b00636, 2018.

Wu, Y. F., Wang, X. J., Tao, J., Huang, R. J., Tian, P., Cao, J. J., Zhang, L. M., Ho, K. F., Han, Z. W., and Zhang, R. J.: Size distribution and source of black carbon aerosol in urban Beijing during winter haze episodes, Atmos. Chem. Phys., 17, 7965-7975, https://doi.org/10.5194/acp-17-7965-2017, 2017.

Zhang, R., Jing, J., Tao, J., Hsu, S. C., Wang, G., Cao, J., Lee, C. S. L., Zhu, L., Chen, Z., Zhao, Y., and Shen, Z.: Chemical characterization and source apportionment of $\mathrm{PM}_{2.5}$ in Beijing: seasonal perspective, Atmos. Chem. Phys., 13, 7053-7074, https://doi.org/10.5194/acp-13-7053-2013, 2013.

Zhang, R. J., Ho, K. F., Cao, J. J., Han, Z. W., Zhang, M. G., Cheng, Y., and Lee, S. C.: Organic carbon and elemental carbon associated with PM10 in Beijing during spring time, J. Hazard. Mater. 172, 970-977, https://doi.org/10.1016/j.jhazmat.2009.07.087, 2009.

Zhang, R. Y., Khalizov, A. F., Pagels, J., Zhang, D., Xue, H. X., and McMurry, P. H.: Variability in morphology, hygroscopicity, and optical properties of soot aerosols during atmospheric processing, P. Natl. Acad. Sci. USA, 105, 10291-10296, https://doi.org/10.1073/pnas.0804860105, 2008.

Zhang, Y. X., Zhang, Q., Cheng, Y. F., Su, H., Li, H. Y., Li, M., Zhang, X., Ding, A. J., and He, K. B.: Amplification of light absorption of black carbon associated with air pollution, Atmos. Chem. Phys., 18, 9879-9896, https://doi.org/10.5194/acp18-9879-2018, 2018. 